\title{
ANALISIS IJĀRAH, WADĪ'AH DAN MASLAHAH TERHADAP TRANSAKSI PENYIMPANAN DARAH TALI PUSAT BAYI DI RUMAH SAKIT MITRA KELUARGA DARMO SATELIT-SURABAYA
}

\author{
Holis \\ Universitas Trunojoyo Madura \\ nurkholismajid.nh@gmail.com
}

\begin{abstract}
This research is field research that discusses the transaction of storing a baby's umbilical cord blood that occurs at the Darmo Satelit-Surabaya "Mitra Keluarga" Hospital in the theoretical perspective of maslahah (benefits), Ijārah (lease) and Wadī'ah (savings). This study proposes two problem formulations, namely: first, a description of the baby's umbilical cord blood storage transactions that occurred at the Darmo Satelit-Surabaya "Mitra Keluarga" Hospital. Two, analysis of maslahah, Ijārah, and Wadī'ah on transactions for storing baby's umbilical cord blood at the Darmo Satelit-Surabaya "Mitra Keluarga" Hospital. The results of the study concluded that the hospital stores umbilical cord blood that has been cut and stored through stem cell transplantation and cell therapy. From the perspective of Ijārah, Wadì'ah, and maslahah, the practice is permissible because there is no element of garār and gives maslahah for human life.
\end{abstract}

Keywords: Islamic law, blood storage, baby's umbilical cord

\begin{abstract}
Abstrak: Penelitian lapangan yang membahas tentang transaksi penyimpanan darah tali pusat bayi yang terjadi di Rumah Sakit "Mitra Keluarga" Darmo Satelit-Surabaya ditinjau dalam perspektif teori maslahah, Ijärah dan Wadi'ah ini akan diurai dengan menjawab dua rumusan masalah, yaitu: pertama, bagaimana transaksi penyimpanan darah tali pusat bayi yang terjadi di Rumah Sakit "Mitra Keluarga" Darmo Satelit Surabaya? bagaimana analisis maslahah, Ijärah, dan Wadī'ah terhadap transaksi penyimpanan darah tali pusat bayi yang terjadi di Rumah Sakit "Mitra Keluarga" Darmo Satelit-Surabaya. Hasil penelitian menyimpulkan bahwa darah tali pusat yang telah dipotong disimpan oleh pihak Rumah Sakit melalui transplantasi sel induk dan melalui terapi sel jika ditinjau dalam perspektif Ijārah, Wadī'ah, dan maslahah, maka praktik itu diperbolehkan karena tidak ada unsur garār dan memberi maslahah untuk kehidupan manusia.
\end{abstract}

Kata Kunci: Hukum Islam, penyimpanan darah, tali pusat bayi

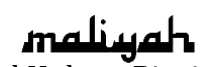

Jurnal Hukum Bisnis Islam

Volume 11, Nomor 01, Juni 2021

p-ISSN: 2088-4869/ e-ISSN: 2597-4351 


\section{Pendahuluan}

Perkembangan zaman yang ditandai dengan perkembangan ilmu pengetahuan dan teknologi dapat memberikan kontribusi yang sangat besar terhadap kemajuan dan perkembangan kehidupan masyarakat. Kemajuan dan perkembangan kehidupan masyarakat tersebut ditandai dengan ditemukannya sejumlah penemuan-penemuan ilmiah yang sangat menakjubkan dan bersifat kontemporer serta dapat dibuktikan dengan ilmu pengetahuan modern melalui proses telaah dan analisis secara cermat dan mendalam. Penemuan-penemuan yang dimaksud juga terjadi di berbagai aspek kehidupan, antara lain di bidang ilmu kesehatan atau ilmu kedokteran. Sebagai salah satu contoh, beberapa dekade terakhir ini masyarakat dihebohkan dengan ditemukannya darah tali pusat bayi yang dapat digunakan sebagai obat penyembuhan terhadap sejumlah penyakit tertentu.

Di sisi lain, ilmu kesehatan atau ilmu kedokteran merupakan salah satu cabang ilmu pengetahuan yang memiliki peran dan fungsi yang sangat esensial demi menjaga dan melestarikan keberlangsungan kehidupan manusia. Dalam hal ini "Rumah sakit merupakan salah satu sarana umum yang memiliki peran penting bagi masyarakat. Pemeliharaan kesehatan merupakan suatu kebutuhan yang menghubungkan masyarakat dengan rumah sakit, sehingga rumah sakit memiliki peran penting yang terlihat secara jelas". ${ }^{1}$

Akan tetapi, dalam realitas kehidupan manusia justru menunjukkan sebaliknya yaitu kebanyakan manusia melupakan dan tidak mampu memanfaatkannya dalam hal kebaikan. Oleh karena itu, Nabi Muhammad SAW mengingatkan kepada manusia agar menjaga kesehatan dan memanfaatkannya untuk hal-hal yang bersifat positif dan dapat memberikan manfaat baik kepada dirinya sendiri maupun kepada orang lain. Nabi Muhammad SAW bersabda:

\footnotetext{
${ }^{1}$ Asep Sudaryanto, "Penahanan Bayi Sebagai Jaminan Persalinan Perspektif Hukum Islam Dan Hukum Positif (KUHPer)", Maliyah: Jurnal Hukum Bisnis Islam, Vol. 07, No. 01, Juni 2017, 38.
}

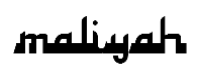

Jurnal Hukum Bisnis Islam 
Holis

"Dari ibn Abbas r.a., beliau berkata, Nabi SAW bersabda: Dua kenikmatan yang sering diabaikan oleh kebanyakan manusia, yaitu kesehatan dan kesempatan". ${ }^{2}$

Pernyataan Nabi SAW. di atas merupakan sinyalemen bagi umat manusia yang menunjukkan bahwa manusia kerap kali mengabaikan kedua nikmat terbesar tersebut. Kaitannya dengan darah tali pusat bayi yang berfungsi untuk menyembuhkan berbagai macam penyakit tertentu, tentunya dara tali pusat bayi tersebut akan menjadi salah satu pilihan yang sangat tepat untuk dimanfaatkan sebagai obat penyembuhan kaitannya dengan upaya menjaga kesehatan.

Di samping itu, kita perlu mengetahui dan memahami gambaran alur atau prosedur terjadinya transaksi penyimpanan darah tali pusat bayi yang terjadi antara kedua belah pihak (pihak pasien dengan pihak dokter), proses pengambilannya, proses penyimpanannya, proses penggunaannya, berapa kadar atau volume darah tali pusat bayi tersebut dapat digunakan, jenis penyakit apa saja yang dapat disembuhkan oleh darah tali pusat bayi, dan hal-hal lain yang berkenaan dengan darah tali pusat bayi tersebut.

Setelah data tersebut dapat dikumpulkan, penulis akan mengkaji dan menelaah terhadap hal-hal yang berkenaan dengan aplikasi terjadinya transaksi penyimpanan darah tali pusat bayi tersebut dengan menggunakan pendekatan hukum Islam, yaitu pendapat fuqah $\bar{a}^{\prime}$ (para pakar hukum Islam) dan berdasarkan pertimbangan faktual yang mengandung banyak mașlaḥah dan manfaat. Hal ini dimaksudkan untuk menjawab dan meyakinkan pasien akan keabsahan transaksi penyimpanan darah tali pusat bayi yang terjadi di Rumah Sakit "Mitra Keluarga" Darmo Satelit-Surabaya berdasarkan hukum Islam. Perlunya legitimasi hukum Islam terhadap transaksi penyimpanan darah tali pusat bayi yang terjadi di Rumah Sakit "Mitra Keluarga" Darmo Satelit-Surabaya, dilatarbelakangi oleh beberapa faktor, antara lain:

${ }^{2}$ Imārah, Mușṭafā Muhammad, Jawāhir al-Bukhāri, Surabaya, cetakan VIII, (alHidāyah: t.t.), 489. 
Analisis Ijārah, Wadīah Dan Maslahah Terhadap ...

Pertama, adanya indikasi penipuan (garār) atau judi (maysìr). Hal ini dapat dilihat dari adanya sejumlah uang yang dijadikan sebagai uang muka yang telah dibayar oleh pihak pasien di awal terjadinya transaksi kepada pihak Rumah Sakit yang diwakili oleh tim dokter yang menanganinya. Selanjutnya hal itu dinyatakan hangus oleh pihak dokter karena berdasarkan uji laboratorium darah tersebut dinyatakan tidak layak untuk disimpan di bank darah tali pusat bayi (cordlife) dikarenakan telah terkontaminasi dengan penyakit-penyakit tertentu yang sangat berbahaya untuk dikonsumsi baik bagi pihak pasien maupun orang lain (keluarganya). ${ }^{3}$

Jika hal ini dipandang dari perspektif hukum Islam, sekilas timbul persoalan yang bersifat kontroversial sehingga perlu adanya kajian dan telaah yang lebih cermat untuk dapat menentukan status hukumnya. Oleh karena itu, untuk dapat memastikan apakah transaksi penyimpanan darah tali pusat bayi yang terjadi di Rumah Sakit "Mitra Keluarga" Darmo Satelit-Surabaya benar-benar mengandung garār (penipuan) dan maysīr (judi) ataukah tidak, penulis merasa perlu untuk mengumpulkan data kaitannya dengan aplikasi transaksi penyimpanan darah tali pusat bayi tersebut.

Selanjutnya, penulis juga akan mengkomparasikannya dengan berbagai macam akad dalam perspektif fuqah $\bar{a}^{\prime}$ Shāfi'iyah (para pakar hukum Islam yang bermazhab kepada Imam al-Syafi'i), serta akan dilakukan analisis dengan menggunakan salah satu dasar pertimbangan dalam penetapan hukum Islam, yaitu teori maslahah dalam pandangan ușūliyyīn (pakar ușūl al-fiqh) yang bermazhab kepada Imam al-Syafi'i.

Kedua, adanya transaksi penyimpanan darah tali pusat bayi yang terjadi di Rumah Sakit "Mitra Keluarga" Darmo SatelitSurabaya yang mengandung dua jenis akad dalam hukum Islam, yaitu Ijārah (sewa) dan Wadī'ah (titipan). Hal ini terlihat sekali pada awal terjadinya kesepakatan antara pihak pasien atau yang mewakilinya yakni (keluarganya) dengan pihak Rumah Sakit yang diwakili oleh tim dokter yang menanganinya.

${ }^{3}$ Djedje Sutedja, Wawancara, Rumah Sakit "Mitra Keluarga" Darmo SatelitSurabaya, 4 Januari 2010. 
Holis

Sebagai konsekuensi dan tindak lanjut dari adanya kesepakatan tersebut, pihak pasien diharuskan untuk membayar sejumlah biaya yang telah ditentukan oleh pihak Rumah Sakit sebagai uang muka, yaitu enam juta lima ratus ribu rupiah dan sakaligus membayar uang sebesar satu juta enam ratus lima puluh ribu rupiah sebagai biaya perawatan darah tersebut selama satu tahun. ${ }^{4}$

Di samping dua alasan di atas yang menuai sejumlah kontroversial dari perspektif fuqah $\bar{a}^{\prime}$, terdapat pula beberapa asumsi masyarakat yang salah kaitannya dengan transaksi penyimpanan darah tali pusat bayi, yaitu adanya pemahaman masyarakat bahwa bayi akan kekurangan darah plasenta bila orang tua memilih untuk mengumpulkan darah tali pusat, dan dengan demikian menimbulkan bahaya serangan anemia pada sang anak di masa depan. ${ }^{5}$ Begitu pula dengan proses pengambilannya yang akan menimbulkan rasa sakit dan resiko yang membahayakan bagi ibu dan anak.

Dari penjelasan di atas, kita dapat mengetahui dan memahami gambaran alur atau prosedur terjadinya transaksi penyimpanan darah tali pusat bayi tersebut, dan sekaligus kita dapat menentukan jenis akad yang digunakan dan status hukumnya. Hubungannya dengan obat penyembuhan, tentulah sangat menarik untuk dikaji dari perspektif fuqahä' (para pakar hukum Islam). Hal ini dimaksudkan untuk mengetahui keabsahan hukumnya secara legal formal.

\section{Definisi, Kandungan, dan Manfaat Darah Tali Pusat Bayi}

Darah tali pusat, juga disebut "darah plasenta", ialah darah yang tertinggal di dalam tali pusat dan plasenta setelah kelahiran dan setelah tali pusat dipotong. Darah tali pusat biasanya dibuang bersama plasenta dan tali pusat. ${ }^{6}$

\footnotetext{
${ }^{4}$ Djedje Sutedja, Wawancara, Rumah Sakit "Mitra Keluarga" Surabaya, 4 Januari 2010.

5 Rumah Sakit "Mitra Keluarga" Darmo Satelit-Surabaya,Teknologi saat ini: Terapi masa depan, mimeo, 27.

${ }^{6}$ Rumah Sakit "Mitra Keluarga" Darmo Satelit-Surabaya, Teknologi Saat Ini: Terapi Masa Depan, mimeo, 20.
}

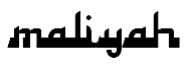


Analisis Ijārah, Wadīah Dan Maslahah Terhadap ...

Berdasarkan hadis Nabi Muhammad SAW empat belas abad yang lalu, yang mengisyaratkan bahwa Tuhan tidak akan menciptakan penyakit tanpa disertai dengan penciptaan obatnya. Di era modern yang ditandai dengan kemajuan dan perkembangan ilmu pengetahuan khususnya ilmu kedokteran, ke-Maha Besaran Allah SWT sudah mulai terkuak dengan ditemukannya hal-hal yang dapat menyembuhkan terhadap sejumlah penyakit tertentu yang lahir dari dirinya sendiri yaitu darah tali pusat bayi.

Pada saat kehamilan, tali pusat berfungsi sebagai garis kehidupan antara sang ibu dan anak. Darah yang ada di dalam tali pusat bayi menawarkan harapan baru bagi sang anak atau anggota keluarga lainnya untuk tetap memelihara kesehatan. Dalam perspektif kedokteran, darah tali pusat merupakan sumber yang kaya akan sel induk haematopoietik, sumber yang terbukti dapat menyembuhkan beberapa penyakit yang diderita manusia, baik penyakit bawaan maupun penyakit akibat unsur eksternal. ${ }^{7}$

Berkaitan dengan sel induk haematopoietik yang berfungsi untuk mengganti dan memperbaiki sistem kekebalan, sel induk ini juga dikenal sebagai prekursor sel-sel karena mereka memiliki kemampuan unik untuk berubah menjadi tipe-tipe sel yang berbeda di dalam darah, yaitu: ${ }^{8}$ (1) sel darah merah yang membawa oksigen ke semua sel dalam tubuh; (2) sel darah putih yang melawan infeksi; (3) keping darah yang membantu pembekuan darah saat terjadi cedera. Sedangkan sumber utama dari sel induk ialah: ${ }^{9}$ (1) sel darah merah; (2) plasma darah; (3) sel berinti

Berdasarkan hasil interview dengan salah seorang pegawai di Rumah Sakit "Mitra Keluarga" Darmo Satelit-Surabaya bahwa tali pusat bayi tersebut dapat digunakan oleh resipien apabila ada kecocokan pada sel berinti yang terkandung dalam darah tali pusat bayi. Adapun sel darah merah dan plasma

\footnotetext{
${ }^{7}$ Ibid.

${ }^{8}$ Ibid.

9 Djedje Sutedja, Wawancara, Rumah Sakit "Mitra Keluarga" Darmo SateliSurabaya, 4 Januari 2010.
} 
Holis

darah tidak diambil dan tidak dimanfaatkan. Oleh karena itu, sel darah tersebut (sel darah merah dan plasma darah) dibuang dan tidak dimanfaatkan lagi. ${ }^{10}$

Dengan demikian, yang menjadi fokus penelitian dan pengujian dokter di laboratorium adalah sel darah berinti. Dan berdasarkan pengalaman, kemungkinan kecocokan sel darah berinti tersebut mencapai $90 \%$ apabila antara keduanya (bayi dan resipien) memiliki hubungan kekeluargaan seperti halnya anak dengan orang tua, kakak dengan adik dan lain sebagainya. Sebaliknya, apabila antara keduanya tidak memiliki hubungan kekerabatan, maka sel darah berinti tersebut seringkali tidak cocok bagi resipien dan tidak dapat digunakan ${ }^{11}$.

Berdasarkan penjelasan di atas dapat disimpulkan bahwa darah tali pusat bayi tersebut juga dapat digunakan oleh orang yang membutuhkannya walaupun secara nasab tidak ada hubungan kekerabatan. oleh karenanya, penulis ingin menjelaskan tentang status kepemilikan darah tali pusat bayi tersebut.

\section{Status Kepemilikan Darah Tali Pusat Bayi}

Kaitannya dengan status kepemilikan darah tali pusat bayi tersebut, hakekatnya darah tali pusat bayi tersebut merupakan hak milik ibu yang melahirkan. Oleh sebab itu, darah tali pusat bayi tersebut tidak boleh digunakan oleh orang lain selain pemiliknya, yaitu ibu. Akan tetapi, realitasnya menunjukkan adanya kemungkinan darah tali pusat bayi yang tidak dimanfaatkan oleh pemiliknya. Hal ini dilatarbelakangi oleh beberapa faktor antara lain: pihak pemiliknya tidak membutuhkan darah tali pusat bayi tersebut atau pihak pemilik tidak berkeinginan untuk menggunakannya. Dalam keadaannya seperti ini, kepada pemiliknya diberikan dua hak opsi, yaitu memberikan kepada pihak lain yang membutuhkannya atau membuangnya secara cuma-Cuma. ${ }^{12}$

\footnotetext{
${ }^{10}$ Ibid.

${ }^{11}$ Ibid.

${ }^{12}$ Ibid.
} 
Analisis Ijārah, Wadīah Dan Maslahah Terhadap ...

Pertama, diberikan kepada orang lain. Dalam kategori pertama, pihak pasien memberikan darah tali pusat bayinya kepada orang lain yang tidak ada hubungan nasab dengan bayi tersebut. Dilihat dari jenis pemberiannya, hal ini dapat dibagi menjadi dua, yaitu: (1) pemberian pihak pemilik kepada orang lain tanpa kompensasi (ganti rugi) sedikitpun. Dalam hal ini, pihak pemilik dengan tulus dan ikhlas melakukan kebaikan dalam bentuk sedekah; (2) pemberian pihak pemilik kepada orang lain dengan sejumlah kompensasi. Dalam hal ini, pihak pemilik bermaksud memberikan darah tali pusat bayinya dengan syarat pihak resipien membayar sejumlah ganti rugi sesuai dengan yang ditentukan oleh pemilik. Dalam konteks ini, perjanjian tersebut telah menyerupai akad bai' (jual beli).

Sedangkan jika dilihat dari segi obyek penerimanya, pemberian darah tali pusat bayi tersebut dapat diklasifikasikan menjadi dua, yaitu: ${ }^{13}$ (1) pihak penerima darah tali pusat bayi adalah pihak Rumah Sakit "Mitra keluarga" Darmo SatelitSurabaya. Pihak Rumah Sakit "Mitra Keluarga" Darmo SatelitSurabaya menerima darah tali pusat bayi yang sudah tidak dimanfaatkan. Hal tersebut dimanfaatkan oleh pihak Rumah Sakit "Mitra Keluarga" Darmo Satelit-Surabaya sebagai bahan uji coba guna kepentingan pengembangan dan penelitian; (2) pihak penerima darah tali pusat bayi adalah orang lain secara individual dengan maksud membantu orang lain, pihak pemilik darah tali pusat bayi memberikannya kepada orang lain guna kepentingan pengobatan dan penyembuhan terhadap penyakit yang dialaminya.

Kedua, membuang darah tali pusat bayi. Pada dasarnya, hak opsi kategori kedua ini merupakan hak mutlak pihak pemilik darah tali pusat bayi. Akan tetapi, berdasarkan pengalaman yang pernah terjadi, kemungkinan pihak pemilik darah tali pusat bayi untuk bisa membuang darah tali pusat bayinya sangat kecil. Hal ini dikarenakan adanya banyak manfaat yang terkandung di dalam darah tali pusat bayi sehingga banyak orang membutuhkannya baik untuk kepentingan penelitian

13 Ibid. 
Holis

dan uji coba maupun kepentingan pribadinya untuk pengobatan berbagai macam penyakit yang dialaminya. ${ }^{14}$

Berkenaan dengan manfaat darah tali pusat bayi penulis tidak mampu menyebutkan satu persatu dan menjelaskannya. Oleh karena itu, penulis akan menjelaskan sebagian jenis penyakit yang dapat disembuhkan dengan menggunakan darah tali pusat bayi, antara lain:

Pertama, memperlambat proses penuaan. Semua sel dalam tubuh manusia melewati proses penuaan secara terus menerus. Proses ini mengakibatkan mutasi, berkurangnya plastisitas dan kapasitas untuk membelah diri sel-sel tersebut. Sel induk darah tali pusat adalah sebuah keajaiban dari suatu proses kelahiran yang menghasilkan sel induk yang "termuda". Sebagai hasilnya, sel tersebut akan menjadi lebih kuat sepuluh kali lipat dari pada sel sumsum tulang orang dewasa. ${ }^{15}$

Kedua, berdasarkan penelitian, sel berinti yang terdapat dalam darah tali pusat bayi telah menyembuhkan lebih dari delapan puluh jenis penyakit, termasuk kanker, sindrom kegagalan sumsum tulang, kelainan darah, kelainan metabolisme turunan, defisiensi kekebalan tubuh. ${ }^{16}$ Beberapa jenis penyakit, mulai dari penyakit ringan sampai penyakit berat yang dapat disembuhkan tersebut semakin menguatkan bahwa ada banyak manfaat yang dikandung oleh sel berinti. Dan manfaat itu adalah untuk kemaslahatan bagi kehidupan manusia.

Ketiga, darah tali pusat kaya akan sel induk hematopoietik, yang merupakan sumber pembentuk darah dan sistem kekebalan tubuh, dan berpotensi membentuk jaringan saraf, kulit, tulang, jantung, organ endokrine dan lain-lain. Dalam satu dekade terakhir, ribuan transplantasi sel induk darah tali pusat telah sukses dilakukan di seluruh dunia. ${ }^{17}$ Sistem kekebalan dalam tubuh manusia merupakan hal sentral dalam

\footnotetext{
${ }^{14}$ Ibid.

${ }^{15}$ Rumah Sakit "Mitra Keluarga” Darmo Satelit-Surabaya, Teknologi Saat Ini: Terapi Masa Depan, mimeo, 23

${ }^{16}$ Ibid.

${ }^{17}$ Ibid.
} 
Analisis Ijārah, Wadīah Dan Maslahah Terhadap ...

metabolisme dan sistem kesehatan manusia untuk bertahan hidup.

\section{Metode Penggunaan Darah Tali Pusat Bayi}

Berkaitan dengan metode penggunaannya, bagaimana pihak pasien dapat menggunakan darah tali pusat bayi yang telah tersedia untuk menyembuhkan penyakit yang dialaminya, berikut penulis akan memaparkan secara lengkap dan keseluruhan tentang metode penggunaannya. ${ }^{18}$

Pertama adalah melalui transplantasi sel induk. Penggunaan darah tali pusat bayi dengan menggunakan metode ini ialah sel induk diinfus secara langsung ke dalam aliran darah pasien, lalu berimigrasi ke sumsum tulang. Di dalam lingkungan sumsum tulang, sel induk mulai berdiferensiasi menjadi tiga jenis sel darah, yakni darah merah, plasma darah, dan keping darah. Hal inilah yang memulai regenerasi darah pasien dan sistem kekebalannya. Dengan demikian tubuh manusia menjadi semakin kuat dan tidak rentan terserang virus.

Kedua adalah melalui terapi sel. Banyak aplikasi-aplikasi yang lebih baru masih menjalani perkembangan. Dalam beberapa kasus, seperti cedera tulang punggung dan serangan jantung, sel-sel langsung diinjeksi ke jaringan yang rusak. Beberapa keuntungan yang dialami antara lain ialah pembentukan pembuluh darah baru, yang memulihkan aliran darah ke jaringan yang rusak. Dalam beberapa kasus, sel induk bisa dikembangkan di laboratorium terlebih dahulu untuk membuat sel baru sebelum digunakan.

\section{Proses Pengambilan dan Penyimpanan Darah Tali Pusat Bayi}

Dalam hal proses pengambilan darah tali pusat bayi yang dilakukan oleh tim dokter dari Rumah Sakit "Mitra Keluarga" Darmo Satelit-Surabaya, terdapat beberapa langkah atau prosedur yang harus dilakukan demi keselamatan ibu dan bayi

${ }^{18}$ Ibid., 21 
yang akan dilahirkannya. Beberapa langkah atau prosedur yang dimaksud ialah: ${ }^{19}$

1. Adanya tes terlebih dahulu terhadap sampel darah pihak ibu, biasanya pada hari kelahiran (baik sebelum ataupun setelah kelahiran bayi). Darah ibu akan dites untuk beberapa penyakit infeksi menular, termasuk HIV, Hepatitis B dan C, dan beberapa penyakit lainnya yang membahayakan. Hal ini penting untuk dilakukan mengingat infeksi dapat terjadi kapan saja sampai tujuh hari sebelum kelahiran.

2. Segera setelah kelahiran bayi, tali pusat akan dijepit dan bayi dipisahkan serta dibawa keluar dari ruang kelahiran.

3. Dokter kemudian akan mengambil darah tali pusat dengan menusukkan jarum ke pembuluh darah tali pusat.

4. Selanjutnya dokter menyimpan darah tali pusat bayi tersebut dengan menggunakan kantong atau syringe. Digunakannya kantong darah atau syringe sebagai alat mengumpulkan darah tali pusat bayi dengan tujuan meminimalkan resiko kontaminasi.

Langkah selanjutnya adalah peroses penyimpanan. Setelah kelahiran dan sebelum darah tali pusat bayi disimpan, darah tali pusat bayi akan diambil oleh tim dokter yang menanganinya dengan cara sebagaimana penjelasan di atas demi kepentingan tes jamur atau bakteri. Perlunya tes jamur atau bakteri untuk dilakukan dikarenakan beberapa faktor, yaitu: (1) adanya resiko kontaminasi bakteri atau jamur selama proses penyimpanan darah tali pusat bayi; (2) memprioritaskan keselamatan ibu; (3) demi memastikan bahwa sel induk tersebut aman digunakan; (3) persyaratan yang wajib dilakukan sebagaimana ketentuan $A A B B$ (akreditasi internasional untuk kedokteran transplantasi).

Setelah darah tali pusat bayi tersebut lulus uji laboratorium dan dinyatakan positif oleh tim dokter (darah tersebut tidak terkontaminasi dan layak untuk disimpan), maka langkah

${ }^{19}$ Djedje Sutedja, wawancara, Rumah Sakit "Mitra Keluarga" Darmo SatelitSurabaya, 4 Januari 2010.

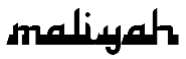


Analisis Ijārah, Wadỉah Dan Maslahah Terhadap ...

berikutnya yang akan dilakukan tim dokter ialah upaya menyimpan darah tali pusat bayi secara baik dan benar. Terkait dengan proses penyimpanannya, darah tersebut disimpan dengan dua cara yaitu: cryobag dan cryovials.

Pertama adalah sistem tertutup (cryobag). Penyimpanan sel induk berinti pada darah tali pusat bayi secara tertutup dilakukan dengan menggunakan sistem triple bag yang tertutup. Artinya, Sistem pemrosesan darah tali pusat bayi dengan menggunakan tiga kantong yang tertutup dan terhubung satu sama lain. Sistem ini memungkinkan pihak dokter untuk memproses sampel darah tali pusat bayi tanpa perlu untuk mengeksposnya ke udara luar di lingkungan sekitar area pemrosesan. Hal ini untuk meminimalisasi resiko kontaminasi dan secara efektif menghilangkan resiko tertukarnya sampel dengan yang lain. ${ }^{20}$

Kedua adalah sistem terbuka (criovials). Penyimpanan dengan tipe kedua ini adalah penyimpanan sel induk berinti pada darah tali pusat bayi dengan menggunakan tabung. Akan tetapi, realitasnya mengindikasikan minimnya penyimpanan darah tali pusat bayi dengan model kedua ini. Komunitas ahli transplantasi sangat menyarankan seluruh Bank Darah Tali Pusat Bayi swasta atau privat untuk mengikuti standar Bank Darah Publik dan menyimpan sel induk dengan menggunakan metode cryobag. ${ }^{21}$

Untuk mendapatkan pengetahuan tentang kelebihan dan kekurangan antara sistem tertutup dan terbuka, maka penulis perlu memberikan penjelasan yang bersifat komparasi (perbandingan) antara keduanya. Perbandingan tersebut ialah:22 (1) dari segi pembiayaannya, metode penyimpanan secara tertutup lebih mahal dari pada metode penyimpanan secara terbuka; (2) dari segi keamanannya, metode penyimpanan secara tertutup lebih aman dari pada metode penyimpanan secara terbuka.

${ }^{20}$ Rumah Sakit "Mitra Keluarga" Darmo Satelit-Surabaya, Teknologi Saat Ini: Terapi Masa Depan, 16.

${ }^{21}$ Ibid.

${ }^{22}$ Ibid. 
Holis

Berkaitan dengan tempat penyimpanan, darah tali pusat bayi disimpan di sebuah lembaga perbankan secara khusus yang disebut dengan (cord life). Cord life adalah sebuah perusahaan penyimpanan darah tali pusat yang mendedikasikan diri untuk memberikan solusi terbaik dalam terapi sel, melalui jaringan bank darah tali pusat yang terluas di Asia dan Australia. ${ }^{23}$ Di Indonesia, cordlife sudah mulai beroperasi sejak tahun 2003. Dengan menggandeng Kalbe Farma, yang merupakan perusahaan farmasi terbesar di Asia Tenggara, cordlife Indonesia secara resmi diluncurkan dengan nama PT. Cordlife Indonesia pada bulan September 2006. ${ }^{24}$

Hubungannya dengan penyimpanan darah tali pusat bayi setelah pengambilan darah tali pusat bayi, pihak Rumah Sakit "Mitra Keluarga" Darmo Satelit-Surabaya langsung mengirimkannya ke Bank Darah Tali Pusat Bayi (cordlife) di Jakarta melalui transportasi udara (pesawat). Dipilihnya pesawat sebagai transportasi utama dalam pengiriman darah tali pusat bayi dimaksudkan agar lebih aman dan efisien serta lebih cepat sampai ke perusahaan cordlife.

Dari sisi kemudahan dan pembayarannya, penyimpanan darah tali pusat bayi pada masa sekarang sangat berbeda dengan masa sebelumnya. Pada masa sebelumnya, Indonesia secara resmi belum mendirikan perusahaan cordlife. Akibatnya, proses penyimpanannya membutuhkan waktu yang relatif cukup lama dan biaya yang relatif tidak terjangkau. Hal ini dikarenakan tidak adanya perusahaan cordlife yang melayani penyimpanan darah tali pusat bayi yang berdiri di Indonesia dan mengharuskan untuk mengirimkannya ke perusahaan cordlife yang berdiri di luar negeri yaitu Singapura.

\section{Aplikasi dan Model Transaksi Darah Tali Pusat Bayi}

Berkenaan dengan aplikasi dan model transaksinya, Bank Darah Tali Pusat Bayi (cordlife) memberikan kemudahan dan kenyamanan bagi Pasiennya. Hal ini dapat dilihat dari adanya pembayaran secara angsuran selama dua kali tahapan. Untuk

${ }^{23}$ Ibid., hal. 4.

${ }^{24}$ Ibid., hal. 5. 
Analisis Ijārah, Wadīah Dan Maslahah Terhadap ...

mengetahui prosedur transaksi penyimpanan darah tali pusat bayi di Rumah Sakit "Mitra Keluarga" Darmo Satelit-Surabaya, penulis melakukan wawancara (interview) dengan salah seorang pegawai Rumah Sakit tersebut yang menghasilkan beberapa penjelasan penting terkait darah tali pusat bayi. ${ }^{25}$

Diantara penjelasan dari hasil wawancara itu adalah: (1) sebelum terjadinya kesepakatan antara kedua belah pihak, tim dokter memberikan informasi kepada pasiennya seputar darah tali pusat bayi hubungannya dengan tujuan dan manfaatnya; (2) setelah terjadi kesepakatan antara kedua belah pihak, pihak dokter mengambil sampel darah tali pusat bayi dari ibu yang melahirkannya guna kepentingan pengujian (tes). Hal ini dimaksudkan untuk mengetahui kelayakan dan kualitas darah tali pusat bayi tersebut; (3) setelah pengujian di laboratorium, pihak dokter akan menginformasikan kepada pihak pasien kaitannya dengan darah tali pusat bayi. Apabila tim dokter menyatakan layak untuk disimpan, sebagai konsekuensinya pihak pasien wajib membayar sejumlah biaya yang telah ditentukan sebesar dua belas juta lima ratus ribu rupiah.

Jumlah biaya ini akan dibayar selama dua kali tahapan. Tahapan pertama, pasien wajib membayar enam juta lima ratus ribu rupiah sebagai uang muka. Berdasarkan hasil wawancara, biaya tersebut dialokasikan untuk biaya pendaftaran sebesar lima ratus ribu rupiah, iaya pengujian di laboratorium sebesar dua juta rupiah, biaya pemrosesan (pengambilan, penggunaan, dan penyimpanannya) sebesar dua juta lima ratus ribu rupiah, dan biaya transportasi sebesar satu juta lima ratus ribu rupiah

Adapun sisanya (enam juta rupiah), akan dibayar oleh pihak pasien setelah pihak pasien melahirkan. Selanjutnya, pihak pasien menunggu proses kelahiran. Setelah kelahiran, tim dokter akan melakukan proses pengambilan dan penyimpanan terhadap darah tali pusat bayi. Dalam rangka untuk memastikan akan kelayakan darah tali pusat bayi tersebut dan sebagai langkah kehati-hatian, pihak dokter kembali melakukan pengujian di laboratorium. Lebih dari itu, tim

25 Djedje Sutedja, wawancara, Rumah Sakit "Mitra Keluarga" Darmo SatelitSurabaya, 4 Januari 2010. 
Holis

dokter akan melakukan pengujian setiap tahun. Pada tahap pengujian kedua kalinya, ada dua kemungkinan yang akan terjadi, yaitu:

Pertama, hasil pengujian tahap kedua sama dengan tahap pertama. Dalam hal ini, proses penyimpanan darah tali pusat bayi tersebut akan dilanjutkan sebagaimana kesepakatan sebelumnya. Sebagai konsekuensinya pihak pasien wajib membayar tahap kedua sebesar enam juta rupiah dan sekaligus termasuk sebagai biaya penyimpanan pada tahun pertama. Pada tahun berikutnya, pasien wajib membayar biaya penyimpanan sebesar satu juta enam ratus lima puluh ribu rupiah per tahun.

Kedua, hasil pengujian tahap kedua tidak sama dengan hasil pengujian pada tahap pertama. Keadaan yang kedua ini mengharuskan adanya pembatalan akad dikarenakan darah tali pusat bayi tersebut tidak layak untuk disimpan dan digunakan baik oleh pihak bayi dan ibunya, keluarganya, maupun orang lain. Hal ini disebabkan darah tali pusat bayi tersebut terkontaminasi virus atau bakteri yang membahayakan. Akibatnya, sejumlah uang enam juta lima ratus ribu rupiah yang telah dibayar di muka dinyatakan hangus dan tidak dapat diambil kembali oleh pihak pasien atau keluarganya.

\section{Aplikasi Transaksi Penyimpanan Darah Tali Pusat Bayi di Rumah Sakit “Mitra Keluarga" Darmo Satelit-Surabaya}

Sebagaimana penjelasan pada bab sebelumnya, transaksi penyimpanan darah tali pusat bayi di Rumah Sakit "Mitra Keluarga" Darmo Satelit-Surabaya dilakukan dengan penuh kehati-hatian serta sedapat mungkin menghidari adanya madarrat (bahaya) yang dimungkinkan akan muncul setelah terjadinya transaksi tersebut. Sikap kehati-hatian tersebut dapat dilihat dari adanya model transaksi yang mengharuskan adanya pembayaran dimuka sebesar enam juta lima ratus ribu rupiah.

Pembayaran sejumlah uang tersebut merupakan kewajiban pihak pasien yang bersifat mutlak. Artinya, jika pihak pasien tidak membayar uang muka sebesar enam juta lima ratus ribu rupiah sebagaimana ketentuan dari pihak Rumah Sakit "Mitra

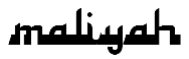


Analisis Ijārah, Wadīah Dan Maslahah Terhadap ...

Keluarga" Darmo Satelit-Surabaya, maka secara sepihak, Pihak Rumah Sakit tersebut "Mitra Keluarga" Darmo Satelit-Surabaya akan membatalkan transaksi penyimpanan darah tali pusat bayi tersebut.

Akibatnya, pihak pasien tidak bisa menggunakan jasa penyimpanan darah tali pusat bayi di Rumah Sakit "Mitra Keluarga" tersebut serta tidak dapat pula mengambil manfaat yang terkandung di dalam darah tali pusat bayi. Dan sebaliknya, jika pasien mampu membayar uang muka tersebut, pihak pasien berhak mendapatkan pelayanan penyimpanan darah tali pusat bayi dan mengambil manfaat dari sel berinti yang terkandung dalam darah tali pusat bayi tersebut.

Pada tahap berikutnya, pihak pasien di wajibkan untuk melunasi kekurangan dari pembayaran pada tahap pertama, yaitu enam juta rupiah. Dengan demikian, dapat disimpulkan bahwa total keseluruan biaya penyimpanan darah tali pusat bayi di Rumah Sakit "Mitra Keluarga" Surabaya sebesar dua belas juta lima ratus ribu rupiah. Diwajibkannya pihak pasien untuk membayar sisa atau kekurangan dari pembayaran tahap pertama, ketika pihak pasien menerima informasi tentang kelayakan darah tali pusat bayi berdasarkan hasil uji laboratorium.

Artinya, pihak pasien wajib membayar kekurangan dari pembayaran pada tahap pertama apabila darah tali pusat bayi tarsebut dinyatakan positif (layak untuk disimpan karena tidak terkontaminasi penyakit) berdasarkan uji di laboratorium. Akan tetapi, jika pihak dokter menyatakan darah tali pusat bayi yang baru dilahirkan oleh pasien tersebut negatif (tidak layak untuk disimpan karena terkontaminasi penyakit) berdasarkan hasil pengujian di laboratorium, maka uang muka yang telah dibayar oleh pihak pasien sebesar enam juta lima ratus ribu rupiah dinyatakan hangus dan tidak dapat diambil kembali.

Berdasarkan penjelasan di atas, kaitannya dengan model transaksi penyimpanan darah tali pusat bayi di Rumah Sakit "Mitra Keluarga" Surabaya, penulis berpendapat bahwa model transaksi penyimpanan darah tali pusat bayi tersebut dibenarkan dalam perspektif fuqahō' Shāfi'iyah. Hal ini dikarenakan untuk kemaslahatan dan keselamatan pihak 
Holis

dokter dari adanya maḍarrah (bahaya) yang akan timbul setelah terjadinya transaksi penyimpanan darah tali pusat bayi yang mengakibatkan kerugian secara finansial yang ditanggung oleh pihak dokter. Dalam rangka untuk menghindari madarrah (bahaya) yang dimungkinkan muncul setelah terjadinya transaksi, penulis membenarkan model transaksi penyimpanan darah tali pusat bayi tersebut sebagaimana yang telah dideskripsikan di atas.

Menurut pandangan penulis, digunakannya model transaksi penyimpanan darah tali pusat bayi sebagaimana penjelasan diatas, yaitu dengan pola pembayaran di awal terjadinya transaksi sebesar enam juta lima ratus ribu rupiah yang dijadikan sebagai uang muka, merupakan langkah kehatihatian dan sangat tepat untuk mengantisipasi adanya madarrah yang dimungkinkan akan timbul setelah terjadinya transaksi antara kedua belah pihak. Disamping itu, model transaksi penyimpanan darah tali pusat bayi tersebut merupakan hasil desain atau modifikasi yang dilakukan oleh umat manusia terhadap berbagai macam transaksi yang secara șarīh (langsung) tidak diatur oleh naș shar'î. Dengan demikian, umat manusia memiliki ruang yang cukup bebas untuk berinovasi dan berkreasi hubungannya dengan muamalah. Hal ini dapat diperkuat dengan al-qawāid al-fiqhiyyah, antara lain:

1. Al-așl fì al-mu'āmalah al-ibāhah illā an yadulla al-dalīl 'alā tahrimiha ${ }^{26}$ (Hukum asal dalam semua bentuk muamalah adalah boleh dilakukan kecuali ada dalil yang mengharamkannya).

2. Kullu sharțin kāna min mașlaḥah al-'aqd au min muqtaḍāhu fahuwa jāizun ${ }^{27}$ (setiap syarat untuk kemaslahatan akad atau diperlukan oleh akad tersebut, maka syarat tersebut dibolehkan).

${ }^{26}$ Ahmad DjazūIi, Kaidah-Kaidah Fikih, Cetakan II (Jakarta, Prenada Media Group: 2007), 185.

27 Ibid. 137

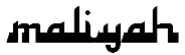


Analisis Ijārah, Wadīah Dan Maslahah Terhadap ...

3. Al-ḍaāru yuzālu ${ }^{28}$ (bahaya atau kemudharatan itu harus dihilangkan).

4. Al-daf'u iqwā min al-raf'î̀ ${ }^{29}$ (mencegah lebih baik dari pada menghilangkannya)

Adapun dalālah (petunjuk makna) yang terkandung di dalam al-qawāid al-fiqhiyyah sebagaimana yang telah disebutkan di atas, ialah diperbolehkannya melakukan sebuah transaksi dengan syarat, selagi syarat tersebut tidak mengandung madarrah (bahaya). Diperbolehkannya melakukan transaksi dengan menggunakan syarat semata-mata dimaksudkan untuk menghindari adanya maḍarrah yang dikhawatirkan akan muncul setelah terjadi transaksi antara kedua belah pihak. Jika hal ini diaplikasikan ke dalam transaksi penyimpanan darah tali pusat bayi di Rumah Sakit "Mitra Keluarga" Darmo Satelit-Surabaya dengan mensyaratkan pihak pasien untuk membayar uang dimuka sebesar enam juta lima ratus ribu rupiah, dapat dibenarkan secara hukum Islam.

Adanya persyaratan bagi pihak pasien untuk membayar uang dimuka, semata-mata untuk menghindari adanya maḍarrah bagi pihak dokter karena pihak pasien tidak membayar kewajibannya. Arti dari kaidah tersebut menunjukkan bahwa kemudharatan itu harus dihilangkan baik yang telah terjadi maupun yang akan terjadi. Apabila demikian halnya, maka wajib dihilangkan. Dasar pertimbangan diberlakukannya ketentuan tersebut ialah untuk menghindarkan sejumlah kemudharatan yang merugikan pihak-pihak yang terlibat didalamnya.

\section{Analisis Ijārah dan Wadī'ah terhadap Transaksi Penyimpanan Darah Tali Pusat Bayi di Rumah Sakit “Mitra Keluarga" Darmo Satelit-Surabaya}

\footnotetext{
${ }^{28}$ Abī al-Faid Muhammad Yāsin İsā al-Fādānī al-Makkī, al-Fawāid al-Janiyyah, Juz I, (Lebanon, Dār al-Fikr: 1997), 246.

${ }^{29}$ Al- Imām Jalāluddin Abd al-Rahmān bin Abī Bakr al-Șuyūtī, al-Asybāh wa al-Naz̄āir fì Qawāid wa Furū' Fiqh al-Syāfi'iyah, Juz I, (Lebanon, Dār al-Kutub al-Ilmiyah: 2005), 299.
} 
Berkenaan dengan model transaksi penyimpanan darah tali pusat bayi di Rumah Sakit "Mitra Keluarga" Darmo SatelitSurabaya sebagaimana prosedur yang telah dideskripsikan pada bab yang lalu, penulis dapat mengklasifikasikan transaksi penyimpanan darah tali pusat bayi tersebut sebagai akad Ijārah (sewa) dan Wadī'ah (titipan). Ijārah dalam paradigma fuqahä' shāfi'iyah didefinisikan sebagai "transaksi terhadap suatu manfaat yang dituju, tertentu, bersifat mubah (sesuatu yang diperbolehkan), dan boleh dimanfaatkan dengan imbalan tertentu".

Sedangkan akad Wadī'ah diartikan sebagai "mewakilkan kepada orang lain untuk memelihara harta yang dimilikinya secara terhormat dan tertentu menurut cara tertentu". Kesamaan atau kemiripan yang terdapat pada transaksi penyimpanan darah tali pusat bayi dengan akad Ijārah dan Wadíah ialah adanya indikasi pemanfaatan pihak pasien terhadap jasa pelayanan tim dokter yang merupakan keahlian dan profesinya hubungannya dengan pemrosesan darah tali pusat bayi mulai dari pengambilan, pengujian di laboratorium, penyimpanan, penggunaan, hingga sistem transaksinya. Artinya, pihak pasien menggunakan keahlian pihak dokter dalam hal pemenuhan kebutuhannya.

Adapun jenis akadnya, akad Ijārah pada transaksi penyimpanan darah tali pusat bayi termasuk Ijārah zimmah. Ijārah zimmah sama halnya dengan akad salām, yang pemanfaatannya tidak secara langsung diperoleh atau dirasakan oleh pihak ājir (penyewa). Dalam konteks ini, penulis sepakat bahwa akad tersebut termasuk akad Ijärah zimmah. Hal ini dikarenakan adanya manfaat yang diperoleh oleh pihak pasien tidak secara langsung, melainkan setelah terjadinya kelahiran.

Terkait dengan definisi yang dikemukakan oleh fuqahä' shāfi'iyah tentang Ijārah, tentunya sangat sesuai jika diaplikasikan pada transaksi penyimpanan darah tali pusat bayi yang terjadi di Rumah Sakit "Mitra Keluarga" Darmo Satelit-Surabaya. Hal ini disebabkan oleh adanya obyek Ijārah berupa manfaat pelayanan medis yang diberikan oleh pihak dokter yang bersifat non materi kepada pihak pihak yang 
Analisis Ijārah, Wadīah Dan Maslahah Terhadap ...

menggunakan jasa tersebut baik dari kalangan internal keluarga besar rumah sakit tersebut maupun masyarakat secara umum.

Di sisi lain, transaksi penyimpanan darah tali pusat bayi juga mengandung unsur kesamaan dengan akad Wadíah dalam perspektif fuqahā' shäfi'iyah. Di identifikasikannya transaksi penyimpanan darah tali pusat bayi tersebut dengan akad Wadī'ah dalam perspektif fuqahā' shäfi'iyah dapat dilihat dari adanya sejumlah biaya yang telah dibayarkan oleh pihak pasien kepada pihak dokter sebesar dua belas juta lima ratus ribu rupiah dan sekaligus akan menjadi biaya penyimpanan pada tahun tersebut (tahun pertama).

Di samping itu, darah tali pusat bayi yang telah diambil oleh pihak dokter tersebut selanjutnya akan disimpan di Bank Darah Tali Pusat Bayi yang disebut dengan cordlife dengan sejumlah biaya yang telah ditentukan oleh pihak dokter. Menurut analisis penulis, indikator yang sangat menekankan adanya kesamaan antara transaksi penyimpanan darah tali pusat bayi tersebut dengan akad Wadī'ah ialah adanya upaya penyimpanan, perawatan, dan pengawasan secara full time (24 jam) yang dilakukan oleh pihak Bank Darah Tali Pusat Bayi (Cordlife). Sedangkan unsur yang membedakan antara akad Wadīah dengan yang lainnya ialah adanya unsur muhāfazah (pengawasan dan pemeliharaan). Dengan demikian, sangatlah jelas bahwa transaksi penyimpanan darah tali pusat bayi di Rumah Sakit "Mitra Keluarga" Darmo Satelit-Surabaya juga mengandung unsur Wadī'ah (titipan).

Dilihat dari Wadī'ah (obyek yang dijadikan akad Wadī'ah), sekilas timbul pertanyaan tentang keabsahan hukumnya. Hal ini dikarenakan yang menjadi obyek Wadi'ah ialah benda yang termasuk kategori najis. Kaitannya dengan benda najis yang menjadi obyek Wadī'ah, penulis lebih sepakat dengan fuqahä' shäfi'iyah yang memperbolehkannya. Hal ini mengingat perkembangan zaman yang sangat pesat yang memotivasi manusia untuk selalu berinovasi dan berkreasi hubungannya dengan upaya menjaga dan melindungi al-qawāid al-khams (kaidah yang lima), yaitu: hifz al- nasl (menjaga keturunan), hifz al-māl (menjaga harta), hifẓ al-dīn (menjaga agama), hifẓ al-nafs 
Holis

(memelihara jiwa), hifz al-'aql (memelihara akal) dan sekaligus ditopang dengan ilmu pengetahuan modern yang berimplikasi pada kemudahan untuk melakukan riset ilmiah yang bersifat kekinian dan mutakhir.

Di samping itu, menurut pandangan penulis, hendaknya lebih mengedepankan dan mengutamakan azas maslahah dan manfaat yang terkandung di dalam darah tali pusat bayi tersebut. Sekalipun darah tali pusat bayi tersebut tergolong sebagai benda najis, tetapi mengandung banyak manfaat bagi yang menggunakannya, penulis lebih sepakat dengan fuqahä' shāfi'iyah yang memperbolehkannya untuk dijadikan obyek berbagai macam transaksi termasuk diantaranya ialah akad Wadī'ah (titipan).

Dalam hal ini, penulis berargumentasi dengan menggunakan pendekatan qiyās (analogi hukum). Sama halnya dengan akad jual beli barang najis, seperti kotoran hewan, fuqah $\bar{a}^{\prime}$ memiliki sejumlah paradigma yang berbeda antara yang satu dengan yang lainnya. Akan tetapi, mengingat manfaat yang terkandung dalam kotoran hewan tersebut sangatlah besar, disamping perkembangan zaman yang menuntut adanya reaktualisasi hukum Islam, penulis sepakat dengan pendapat Imam Hanafi yang memperbolehkannya.

Adapun kaidah yang menguatkan dan mengakui adanya perubahan hukum yang disebabkan oleh illat al-hukm (motivasi atau alasan hukum) adalah taghayyur al-fatwā wa ikhtilāfihä bihasbi taghayyur al-azminah wa al-amkinah wa alaḥwāl wa al-niyyāt wa 'awāid (Perubahan fatwa hukum tentang suatu masalah disebabkan oleh adanya perubahan waktu, tempat, kondisi, niat dan adat kebiasaan yang ada pada wilayah setempat). ${ }^{30}$

Berkenaan dengan darah tali pusat bayi, pada dasarnya yang menjadi obyek akad Wadīah ialah bukan barang yang telah diambil oleh pihak dokter yang berstatus najis, melainkan sel darah berinti yang terkandung di dalam darah tali pusat bayi tersebut. Dengan demikian, yang menjadi obyek dalam akad ini ialah bukan benda najis, melainkan suci. Oleh

${ }^{30}$ Ahmad Djazuli, Kaidah-Kaidah Fikih, 14. 
Analisis Ijārah, Wadīah Dan Maslahah Terhadap ...

karena itu, status hukum dari akad penyimpanan dan penitipan objek berupa bank darah tali pusar bayi adalah mubāh (boleh).

Menurut analisis penulis terkait dengan jenis akadnya dalam perspektif fuqahä' shäfi'iyah, transaksi penyimpanan darah tali pusat bayi di Rumah Sakit "Mitra Keluarga" Darmo Satelit-Surabaya dapat diklasifikasikan sebagai akad Wadīah yad amānah. Adapun alasannya ialah adanya larangan bagi pihak Rumah Sakit "Mitra Keluarga" untuk memanfaatkan darah tersebut tanpa seizin pihak al-mālik (orang yang memilikinya) setelah terjadinya transaksi tersebut. Oleh karenanya, pihak muwadda' (pihak yang dititipi) tidak bertanggung jawab atas kerusakan atau kehilangan benda titipan tersebut tanpa adanya indikator yang membuktikan bahwa pihak muwadda' (pihak yang dititipi) dengan sengaja lalai dan tidak melaksanakan tugas dan kewajibannya dalam kapasitasnya sebagai penanggung jawab.

Sebagai konsekuensinya, pihak Rumah Sakit "Mitra Keluarga" Darmo Satelit-Surabaya tidak diperbolehkan memungut biaya apapun kecuali biaya perawatan dan operasional lainnya. Realitasnya, pihak Rumah Sakit "Mitra Keluarga" Darmo Satelit-Surabaya memang tidak memungut biaya dari pihak pasien melainkan biaya perawatan darah tali pusat bayi tersebut sebesar satu juta enam ratus lima puluh ribu rupiah per tahun. Dengan demikian, transaksi penyimpanan darah tali pusat bayi tersebut tidak bertentangan dengan teori fiqh dalam perspektif fuqahā' shāfi'iyah.

\section{Analisis Maslahah terhadap Transaksi Penyimpanan Darah Tali Pusat Bayi di Rumah Sakit "Mitra Keluarga" Darmo Satelit-Surabaya.}

Sebagaimana penjelasan pada bab yang lalu tentang model transaksi penyimpanan darah tali pusat bayi yang dilakukan oleh pihak Rumah Sakit "Mitra Keluarga" Darmo SatelitSurabaya yang mensyaratkan pihak pasien untuk membayar uang muka terlebih dahulu sebesar enam juta lima ratus ribu rupiah dan uang tersebut akan dinyatakan hangus apabila berdasarkan uji laboratorium darah tali pusat bayi tersebut ternyata tidak layak untuk disimpan, termasuk model transaksi 
Holis

yang tidak ada nașs shar'ī yang melegitimasi dan membatalkannya baik secara langsung ataupun tidak langsung. Dengan demikian, transaksi penyimpanan darah tali pusat bayi dengan model seperti ini dapat dikaji dengan menggunakan salah satu dasar pertimbangan dalam penetapan hukum Islam, yaitu maslahah. Hal ini dimaksudkan untuk mengetahui keabsahan model transaksi penyimpanan darah tali pusat bayi tersebut dalam perspektif hukum Islam.

Menurut analisis penulis, ditinjau dari aspek tingkat kebutuhannya, transaksi penyimpanan darah tali pusat bayi tersebut termasuk mașlaḥah ḍarūiyah. Diklasifikannya model transaksi tersebut dengan mașlahah darūriyah dikarenakan adanya upaya untuk menjaga salah satu al-qawāid al- khams (lima kaidah dasar) yaitu hifz al-māl (menjaga harta). Hal ini dapat dilihat dari adanya indikasi sikap kehati-hatian yang dilakukan oleh pihak Rumah Sakit "Mitra Keluarga" Darmo Satelit-Surabaya. Sikap kehati-hatian tersebut diwujudkan oleh pihak Rumah Sakit "Mitra Keluarga" dengan cara pembayaran dimuka.

Apabila pihak Rumah Sakit "Mitra Keluarga" Darmo SatelitSurabaya tidak mewajibkan pihak pasien untuk melakukan pembayaran dimuka sebesar enam juta lima ratus ribu rupiah, dapat dimungkinkan pihak pasien akan melarikan diri dan tidak melaksanakan kewajibannya sebagaimana perjanjian yang telah disepakatinya yaitu melunasi kekurangan pembayarannya sebesar enam juta rupiah, padahal pihak pasien telah menggunakan jasa pelayanan dokter berupa pemerikasaan, pengujian di laboratorium, pengambilan, penyimpanan, hingga penggunaannya. Hal tersebut akan membawa bahaya bagi pihak dokter berupa kerugian secara finansial.

Di sisi lain, agama Islam memerintahkan agar kemungkinan kerugian yang akan timbul dapat dihindari. Hal ini sebagaimana kaidah fiqh, yang berbunyi dar'u al-mafäsid muqaddam 'alā jalb al-mașālih (menolak bahaya lebih didahulukan dari pada mendatangkan manfaat). ${ }^{31}$ Kaidah fikih

${ }^{31}$ Abdul Hamid Hakim, Assullam, (Jakarta, Sa'adiyah Putra: 2007), 72. 
Analisis Ijārah, Wadīah Dan Maslahah Terhadap ...

ini semakin memperkuat bahwa menghindarkan diri dari bahaya yang ditimbulkan akibat semua biaya yang harus ditanggung pihak Rumah Sakit terhadap perawatan, pemerikasaan, pengujian di laboratorium, pengambilan, penyimpanan, hingga penggunaannya harus diutamakan.

Dilihat dari aspek kehujjahannya, model transaksi penyimpanan darah tali pusat bayi tersebut menempati posisi mașlaḥah mursalah. Hal ini dikarenakan tidak adanya nașs shar'ī yang secara tegas atau langsung memperbolehkan atau tidak memperbolehkan transaksi penyimpanan darah tali pusat bayi tersebut. Mengacu kepada hadis dan kaidah fikih di atas, yang mengisyaratkan adanya larangan untuk berbuat maḍarrah (bahaya) baik bagi dirinya sendiri maupun orang lain, model transaksi penyimpanan darah tali pusat bayi tersebut dapat dibenarkan dalam perspektif hukum Islam dengan menggunakan salah satu dasar pertimbangan dalam penetapan hukum Islam dengan menggunakan konsep mașlaḥah.

Di samping itu, kemaslahatan yang terdapat pada model transaksi penyimpanan darah tali pusat bayi tersebut dapat dianalogikan dengan kemaslahatan yang terdapat pada upaya sahabat Abu Bakr atas inisiatif sahabat Umar bin Khattab untuk mengumpulkan dan mengkodifikasikan mushaf Al-Qur'an. Adapun dasar pertimbangan sahabat pada masa itu ialah maslahah. Hal ini disebabkan tidak adanya naș shar'i yang memerintahkan untuk melakukan kodifikasi Al-Qur'an maupun yang melarangnya. Dalam pandangan sahabat, andaikan AlQur'an tersebut tidak dikodifikasikan menjadi satu mushaf, maka akan menimbulkan banyak kesulitan dan keraguan akan keotentikan Al-Qur'an baik pada masa itu maupun pada masa sekarang. Hal ini disebabkan hilangnya tulisan-tulisan AlQur'an sebagaimana yang pernah dibacakan oleh Nabi Muhammad SAW dan bercampur baurnya Al-Qur'an tersebut dengan tulisan-tulisan orang yang ahli bid'ah.

Di sisi lain, walaupun kemaslahatan yang terkandung pada model transaksi penyimpanan darah tali pusat bayi sebagaimana penjelasan di atas tidak dijelaskan secara detail dalam nașs shar'i baik dari Al-Qur'an maupun hadis Nabi 
Holis

Muhammad SAW., akan tetapi kemaslahatan tersebut merupakan hasil pengamatan induksi dari berbagai naș shar'i baik dari Al-Qur'an maupun hadis Nabi SAW, yang intinya adalah bahwa segala sesuat yang memiliki kandungan maslahah adalah baik bagi kehidupan manusia, di atara AlQur'an yang berbicara tentang maslahah adalah antara lain:

"Hai orang-orang yang beriman, janganlah kamu saling memakan harta sesamamu dengan jalan yang batil, kecuali dengan jalan perniagaan yang Berlaku dengan suka samasuka di antara kamu. dan janganlah kamu membunuh dirimu, sesungguhnya Allah adalah Maha Penyayang kepadamu". ${ }^{32}$

Pada dasarnya, ayat di atas menjelaskan tentang larangan untuk memakan harta orang lain dengan cara yang bātil. Menurut perspektif penulis, ayat tersebut lebih menekankan kepada cara yang digunakan oleh seseorang untuk memperoleh harta yang selanjutnya akan digunakan untuk memenuhi kebutuhan hidupnya (dikonsumsi). Dengan demikian, adanya larangan dari ayat tersebut bukan hanya kaitannya dengan cara yang digunakan untuk mendapatkan harta tetapi juga berlaku pada setiap transaksi yang menggunakan cara yang bāțil.

Menurut $A b u$ Ja'far yang di nukil oleh al-Tabari dalam kitabnya tafsir al-Ṭabari bahwa kata "bāțil" tersebut mencakup makna riba (tambahan), qimar (judi), dan cara-cara lain yang dilarang oleh Allah SWT. Hubungannya dengan model transaksi penyimpanan darah tali pusat bayi, yang mengharuskan adanya pembayaran di muka dimaksudkan untuk menghindari adanya madarrah (bahaya) merupakan illah (penyebab) yang menyababkan diperbolehkannya suatu transaksi termasuk diantaranya transaksi penyimpanan darah tali pusat di Rumah Sakit "Mitra Keluarga” Darmo Satelit-Surabaya.

"Dari Ibn Abbas r.a., Dia berkata: Rasul SAW bersabda: Janganlah berbuat sesuatu yang membawa maḍarrah (bahaya) baik bagi dirinya sendiri maupun orang lain". ${ }^{33}$

32 Departemen Agama RI, Al-Qur'ān dan Terjemahannya, (Bandung, Penerbit Diponegoro: 2009), 83.

33 Al-Ṣan'āni, Subul al-Salām, Jilid III, (Surabaya, al-Hidāyah, t.t.), 84. 
Hadis tersebut di atas mengisyaratkan adanya larangan untuk melakukan sesuatu yang mengandung madarrah baik bagi dirinya sendiri maupun orang lain. Jika hal ini diaplikasikan kepada model transaksi penyimpanan darah tali pusat bayi yang terjadi di Rumah Sakit "Mitra Keluarga” Darmo Satelit-Surabaya, tentunya sangat tepat. Dibenarkannya transaksi penyimpanan darah tali pusat bayi tersebut dengan menggunakan hadis ini, dikarenakan model transaksi penyimpanan darah tali pusat bayi dengan mensyaratkan pihak pasien untuk membayar sejumlah biaya yang ditentukan diawal terjadinya transaksi, semata-mata dimaksudkan untuk menghindari adanya madarrah yang dimungkinkan muncul setelah terjadinya transaksi antara kedua belah pihak.

Dengan pertimbangan untuk menghindari kemungkinan adanya madarrah, dan sekeligus berdasarkan induksi dari sejumlah dalil yang melarang adanya madarrah tersebut, transaksi penyimpanan darah tali pusat bayi yang terjadi di Rumah Sakit "Mitra Keluarga" Surabaya dapat dibenarkan dalam perspektif hukum Islam.

\section{Penutup}

Darah tali pusat yang telah dipotong disimpan oleh pihak Rumah Sakit melalui transplantasi sel induk dan melalui terapi sel. Langkah selanjutnya adalah peroses penyimpanan. Setelah kelahiran dan sebelum darah tali pusat bayi disimpan, darah tali pusat bayi akan diambil oleh tim dokter dengan dua cara yaitu cryobag dan cryovials. Cryobag adalah penyimpanan sel induk berinti pada darah tali pusat bayi secara tertutup dilakukan dengan menggunakan sistem triple bag yang tertutup. Dan criovials adalah penyimpanan dengan tipe kedua ini adalah penyimpanan sel induk berinti pada darah tali pusat bayi dengan menggunakan tabung.

Menurut analisis Ijārah dan Wadī'ah, transaksi penyimpanan darah tali pusat bayi di Rumah Sakit "Mitra Keluarga" Darmo Satelit-Surabaya adalah boleh karena sewa dan jasa penitipan diperbolehkan dalam Islam selama kedua belah pihak saling mendapatkan keuntungan dan terdapat 
Holis

kejelasan barang yang menjadi objek sewa dan penitipan. Sedangkan dalam perspektif maslahah, praktik ini termasuk mașlahah ḍarūriyah karena adanya upaya untuk menjaga salah satu al-qawāid al- khams (lima kaidah dasar) yaitu hifz al-māl (menjaga harta) dan hifz al-nafs (menjaga jiwa) karena bisa dipergunakan untuk pengobatan demi kesehatan dan keselamatan jiwa manusia

\section{Daftar Pustaka}

Departemen Agama RI, Al-Qur'ān dan Terjemahannya, Bandung, Penerbit Diponegoro: 2009.

Djazūli, Ahmad, Kaidah-Kaidah Fikih, Cetakan II, Jakarta, Prenada Media Group: 2007.

Hakim, Abdul Hamid, Assullam, Jakarta, Sa'adiyah Putra: 2007. Imārah, Mușțafā Muhammad, Jawāhir al-Bukhāri, Surabaya, cetakan VIII, al-Hidāyah: t.t..

Maliki (al), Abī al-Faid Muhammad Yāsin Īsā al-Fādānī, alFawāid al-Janiyyah, Juz I, Lebanon, Dār al-Fikr: 1997.

Rumah Sakit "Mitra Keluarga" Darmo Satelit-Surabaya,

Teknologi saat ini: Terapi Masa Depan, Mimeo.

Șan'āni (al), Subul al-Salām, Jilid III, Surabaya, al-Hidāyah, t.t.. Sudaryanto, Asep, "Penahanan Bayi Sebagai Jaminan Persalinan Perspektif Hukum Islam Dan Hukum Positif (KUHPer)”, Maliyah: Jurnal Hukum Bisnis Islam, Vol. 07, No. 01, Juni 2017.

Sutdja, Djedje, wawancara, Rumah Sakit "Mitra Keluarga" Darmo Satelit-Surabaya, 4 Januari 2010.

Suyuti (al), Al- Imām Jalāluddīn Abd al-Rahmān bin Abī Bakr, al-Asybāh wa al-Nazāir fi Qawāid wa Furū' Fiqh alSyāfi'iyah, Juz I, Lebanon, Dār al-Kutub al-Ilmiyah: 2005. 